Article

\title{
Sustainability Evaluation of Immobilized Acid-Adapted Microalgal Technology in Acid Mine Drainage Remediation following Emergy and Carbon Footprint Analysis
}

\author{
Kuppan Praveen ${ }^{1}$, Sudharsanam Abinandan ${ }^{1,2}$ (D), Kadiyala Venkateswarlu ${ }^{3}$ and Mallavarapu Megharaj ${ }^{1,2, *(\mathbb{D})}$ \\ 1 Global Centre for Environmental Remediation (GCER), ATC Building, College of Engineering Science and \\ Environment, University of Newcastle, Callaghan, NSW 2308, Australia; Praveen.Kuppan@uon.edu.au (K.P.); \\ abinandan.sudharsanam@newcastle.edu.au (S.A.) \\ 2 Cooperative Research Centre for Contamination Assessment and Remediation of Environment (CRC CARE), \\ ATC Building, University of Newcastle, Callaghan, NSW 2308, Australia \\ 3 Formerly Department of Microbiology, Sri Krishnadevaraya University, Anantapuramu 515003, India; \\ venkateswarlu.kadiyala@gmail.com \\ * Correspondence: megh.mallavarapu@newcastle.edu.au
}

check for

updates

Citation: Praveen, K.; Abinandan, S.; Venkateswarlu, K.; Megharaj, M.

Sustainability Evaluation of Immobilized Acid-Adapted Microalgal Technology in Acid Mine Drainage Remediation following Emergy and Carbon Footprint Analysis. Molecules 2022, 27, 1015. https://doi.org/10.3390/molecules 27031015

Academic Editor: Hussein Znad

Received: 27 December 2021

Accepted: 31 January 2022

Published: 2 February 2022

Publisher's Note: MDPI stays neutral with regard to jurisdictional claims in published maps and institutional affiliations.

Copyright: (C) 2022 by the authors. Licensee MDPI, Basel, Switzerland. This article is an open access article distributed under the terms and conditions of the Creative Commons Attribution (CC BY) license (https:// creativecommons.org/licenses/by/ $4.0 /)$.

\begin{abstract}
Sustainability evaluation of wastewater treatment helps to reduce greenhouse gas emissions, as it emphasizes the development of green technologies and optimum resource use rather than the end-of-pipe treatment. The conventional approaches for treating acid mine drainages (AMDs) are efficient; however, they need enormous amounts of energy, making them less sustainable and causing greater environmental concern. We recently demonstrated the potential of immobilized acid-adapted microalgal technology for AMD remediation. Here, this novel approach has been evaluated following emergy and carbon footprint analysis for its sustainability in AMD treatment. Our results showed that imported energy inputs contributed significantly $(>90 \%)$ to the overall emergy and were much lower than in passive and active treatment systems. The microalgal treatment required 2-15 times more renewable inputs than the other two treatment systems. Additionally, the emergy indices indicated higher environmental loading ratio and lower per cent renewability, suggesting the need for adequate renewable inputs in the immobilized microalgal system. The emergy yield ratio for biodiesel production from the microalgal biomass after AMD treatment was $>1.0$, which indicates a better emergy return on total emergy spent. Based on greenhouse gas emissions, carbon footprint analysis (CFA), was performed using default emission factors, in accordance with the IPCC standards and the National Greenhouse Energy Reporting (NGER) program of Australia. Interestingly, CFA of acid-adapted microalgal technology revealed significant greenhouse gas emissions due to usage of various construction materials as per IPCC, while SCOPE 2 emissions from purchased electricity were evident as per NGER. Our findings indicate that the immobilized microalgal technology is highly sustainable in AMD treatment, and its potential could be realized further by including solar energy into the overall treatment system.
\end{abstract}

Keywords: immobilized microalgae; AMD bioremediation; sustainability; emergy; carbon footprint; NGER; IPCC

\section{Introduction}

Acid mine drainage (AMD), caused by the oxidation of iron sulfide minerals, results in acidic, sulfate-rich water with a low $\mathrm{pH}$ and enhanced metal bioavailability that may have serious health and environmental consequences [1]. AMD forms from mining waste rocks, tailings, and mine pits, and it has a wide range of chemical properties, posing a major challenge to the treatment process [2,3]. The efficacy of treatment processes including precipitation, adsorption, electrochemistry, and membrane filtration is influenced by low $\mathrm{pH}$ and the presence of high metal concentrations [4]. Chemicals used in the active treatment 
system of AMD include limestone, hydrated lime, soda ash, caustic soda, ammonia, calcium peroxide, kiln dust, and fly ash [2]. The selection of an AMD treatment approach has traditionally been guided by technical and economic reasons, with environmental performance being a secondary consideration. The long-term durability of remediation systems, on the other hand, is becoming more important in making clear recommendations [5]. As a result, significant efforts have been made to promote an energy-efficient and ecologically friendly wastewater treatment system for AMD [6]. In addition to pollutant removal and achieving the effluent discharge requirement, environmental consequences of chemical and energy consumption, and greenhouse gas (GHG) emissions created by the wastewater treatment process attracted more attention from the environmental scientists [7]. Unlike traditional treatment methods, biological treatments, such as microalgae-based, process utilize $\mathrm{CO}_{2}$, wastewater nutrients and sunlight for growth, and present an economic potential for value-added products from algal biomass [8-10]. Microalgal technology not only aids in wastewater treatment, but also provides significant environmental, economic, and social advantages by reducing chemical consumption and net pollutant emissions [11-14].

Life cycle assessment (LCA) is an integrated approach for evaluating the environmental implications of a product or process as well as factors that are undermined in more conventional treatments such as raw material extraction, material transit, and final product disposal $[15,16]$. Furthermore, only limited investigations have shown the LCA analysis for AMD treatment method [5,17]. Although LCA is a valuable tool for measuring environmental effect, it does not consider the free ecosystem input of the process. Moreover, the amount of natural resource renewability and the planet's ability to absorb the effects of the manufacturing process have an impact on environmental sustainability and, as a result, repeatability through time [18]. Any approach that considers both the environmental and sustainability aspects of energy systems coupled with the thermos-economic evaluation might be a good substitute. Traditional energy analysis and economic approaches as well as ecological inputs and services have little use in the creation of commercial viability. Reporting for nature's input is critical for a quantitative knowledge of the interaction between the production system and the biosphere, which is critical for sustainability analysis. Researchers have employed thermodynamic concepts such as matter, energy, and entropy as well as net energy, material yield, and environmental loading to analyze sustainability.

To address the inadequacies of treatment systems, Odum [19] applied emergy analysis, which differentiates free resources (renewable and non-renewable) from those that are acquired. Consequently, a set of emergy indicators and ratios are used to examine the resources from various categories and their influence on emissions. Embodied energy analysis (EEA), which calculates the necessary commercial energy (only includes fossil energy) to generate goods or services, and exergy analysis, which offers only the maximum theoretical work of process in each context, are the two examples of emergy analysis. However, turning all input streams into emergy has a larger boundary and is deemed more complete to measure the ecological cost and relative environmental loss of a system [20]. This feature distinguishes emergy as a compelling alternative for assessing sustainability, which aids decision-making on energy, environmental, and social challenges [21]. Such advancements are most likely to aid in the adoption of industrial practices, allowing for sustainable growth and, as a result, resource conservation in the future. Emergy has been utilized effectively on a variety of systems on many scales in ecological and economic value [22]. Bjorklund et al. [23] conducted an emergy study for a sludge digestionbased integrated wastewater treatment and energy generating system and claimed that wastewater has high emergy content and justified the use of various resources in the treatment process. Zhang et al. [24] also used emergy analysis in scenarios including sewage treatment, treated water discharge, and sludge management for environmental pressure and economic performance. Similarly, CFA accounts for the direct and indirect $\mathrm{CO}_{2}$ emissions for each kind of material (concrete, fuel, etc.) or service (material delivery, energy, etc.) used in a treatment system [25-27]. Even though CFA methodologies vary, consultants often employ a cross approach that considers both the inputs and outputs of 
a manufacturing process throughout the development and operation. Similar to emergy analysis, CFA makes comparisons using a single unit and the mass of $\mathrm{CO}_{2}$ equivalents $\left(\mathrm{CO}_{2} \mathrm{e}\right)$. This implies that both the methods are complimentary as the emergy analysis takes an "upstream" approach, evaluating a system based on the quantity of solar emjoules needed, while CFA is often a "downstream" method. In all, the environmental effect of a system's operations is analyzed, which can contribute to more robust and sustainable accounting systems [26,27].

Recently, we used acid-adapted microalgal strains, Desmodesmus sp. MAS1 and Heterochlorella sp. MAS3, to evaluate the immobilized technology for treating synthetic acid mine drainage and demonstrated significant biomass production and iron recovery [4]. Moreover, using LCA to examine the environmental sustainability of the immobilized technology in AMD treatment, we observed minimal energy usage and low emission of GHG as compared to the traditional and hybrid treatment techniques [25]. In the present unique study, we used emergy and carbon footprint analysis to evaluate the immobilized acid-adapted microalgal technology as an effective approach for AMD bioremediation. In fact, the Federal Government of Australia mandated, through NGER system, the threshold criteria for greenhouse gas emissions [28]. Therefore, in the current research, extra analysis was carried out in accordance with the Australian National Greenhouse Gas Reporting Systems to cross-validate the CFA.

\section{Results and Discussion}

\subsection{Emergy Flow in Immobilized Acid-Adapted Microalgal System}

The emergy flow diagram indicating the details of inputs, output, and internal material flow of acid-adapted microalgal technology for AMD remediation is presented in Figure 1. AMD and water were the major locally available renewable and non-renewable inputs, respectively, for the systems, while biodiesel from the biomass and algal residue were the by-products from the system. The major loss of water due to evaporation in the present system was considered in biodiesel production. da Cruz and Nascimento [29] also reported that water alone accounted for the major energy loss in renewable flow of oil production from microalgal biomass. The results from emergy analysis of the acid-adapted microalgal system for AMD treatment are presented in Table 1. In the present emergy flow, natural renewable inputs $(0.43 \%)$, non-renewable inputs $(0.05 \%)$ and imported inputs $(>99 \%)$ were the major contributors to the overall emergy value of $1010 \times 10^{15}$ sej for AMD treatment (Table 2). Similarly, Winfrey et al. [27] reported the implication of 94 and 99\% imported inputs in active and passive systems, respectively, for treating net alkaline mine drainage. In addition, the overall emergy value obtained for acid-adapted microalgal strains was $87-140 \%$ lower than that of passive and active treatment systems [27]. This is due to the less consumption of imported materials used in the treatment system despite the lesser renewable input. Maiolo et al. [18] considered geothermal heat flow, tidal energy, wind, wave energy and rain as renewable input flow for production of dried microalgal biomass from Tetraselmis suecica and Tisochrysis lutea during outdoor cultivation using flat panel photobioreactor. Similarly, natural renewable input accounted for 7 and $<0.01 \%$ in the passive and active treatment system, respectively [27]. In the present study, solar energy and water were the major renewable and non-renewable inputs used for the microalgalbased AMD treatment in a photobioreactor. The main advantage of the microalgae-based technology is the use of biomass for biodiesel production following in situ transesterification process where the yield of biodiesel is around $10 \%$ [25], which is equivalent to $3.65 \times 10^{17}$ sej and 35\% of overall emergy value. However, conventional extraction process of biodiesel from microalgal biomass showed that $59.40 \%$ of energy could be attributed to the overall emergy value [18]. Furthermore, enhanced hexane consumption and water loss caused by evaporation during extraction process also accounted for $>7 \%$ of total emergy used by the system as reported recently by Maiolo et al. [18]. 
Table 1. Emergy calculations for microalgae-based AMD treatment and biodiesel production.

\begin{tabular}{|c|c|c|c|c|c|}
\hline Type of Flow & Item of Emergy Flow (Unit) & Unit Value & $\begin{array}{l}\text { Transformity } \\
\text { (Sej/Unit) }\end{array}$ & $\begin{array}{l}\text { Emergy } \\
\text { (Sej/y) }\end{array}$ & Reference \\
\hline \multirow{3}{*}{$\mathrm{R}$} & $\begin{array}{l}\text { Locally available } \\
\text { renewable inputs }\end{array}$ & & & & \\
\hline & Solar energy $(\mathrm{J})$ & $3.69 \times 10^{13}$ & 1.00 & $3.69 \times 10^{13}$ & [30] \\
\hline & AMD inflow (J) & $2.35 \times 10^{9}$ & $3.80 \times 10^{6}$ & $8.92 \times 10^{15}$ & [23] \\
\hline \multirow{3}{*}{$\mathrm{N}$} & $\begin{array}{l}\text { Locally available } \\
\text { non-renewable } \\
\text { inputs }\end{array}$ & & & & \\
\hline & Land use $\left(\mathrm{m}^{2}\right)$ & $1.00 \times 10^{4}$ & $8.67 \times 10^{10}$ & $8.67 \times 10^{14}$ & [31] \\
\hline & Water for Biodiesel (J) & $4.32 \times 10^{7}$ & $7.30 \times 10^{6}$ & $3.15 \times 10^{14}$ & [32] \\
\hline \multirow{7}{*}{$\mathrm{F}$} & $\begin{array}{l}\text { Imported inputs in } \\
\text { AMD treatment }\end{array}$ & & & & \\
\hline & $\begin{array}{l}\text { Algal biomass- } \\
\text { Inoculum }(\mathrm{g})\end{array}$ & $1.58 \times 10^{9}$ & $3.16 \times 10^{7}$ & $5.00 \times 10^{16}$ & [29] \\
\hline & PBR - PVC (g) & $1.62 \times 10^{7}$ & $9.09 \times 10^{9}$ & $1.48 \times 10^{17}$ & [18] \\
\hline & Electricity $(\mathrm{J})$ & $3.85 \times 10^{7}$ & $1.19 \times 10^{5}$ & $4.58 \times 10^{12}$ & \multirow{4}{*}{ [32] } \\
\hline & PBR steel (g) & $2.40 \times 10^{8}$ & $1.80 \times 10^{9}$ & $4.32 \times 10^{17}$ & \\
\hline & PBR concrete (g) & $1.02 \times 10^{6}$ & $1.09 \times 10^{9}$ & $1.11 \times 10^{15}$ & \\
\hline & Labor $(\mathrm{J})$ & $2.19 \times 10^{3}$ & $7.44 \times 10^{6}$ & $1.63 \times 10^{10}$ & \\
\hline \multirow{3}{*}{ Y } & $\begin{array}{l}\text { Output after } \\
\text { treatment }\end{array}$ & & & & \\
\hline & Algal wet weight & $1.62 \times 10^{9}$ & $9.07 \times 10^{7}$ & $1.47 \times 10^{17}$ & [32] \\
\hline & $\begin{array}{l}\text { Treated AMD } \\
\text { outflow (J) }\end{array}$ & $2.35 \times 10^{9}$ & $4.99 \times 10^{6}$ & $1.17 \times 10^{16}$ & [33] \\
\hline \multirow{9}{*}{$\mathrm{F}$} & $\begin{array}{l}\text { Imported inputs in Biodiesel } \\
\text { production }\end{array}$ & & & & \\
\hline & Steel $(\mathrm{g})$ & $1.94 \times 10^{4}$ & $1.80 \times 10^{9}$ & $3.50 \times 10^{13}$ & \multirow{8}{*}{ [32] } \\
\hline & Concrete (g) & $1.75 \times 10^{5}$ & $1.09 \times 10^{9}$ & $1.91 \times 10^{14}$ & \\
\hline & Electricity $(\mathrm{J})$ & $2.31 \times 10^{9}$ & $1.19 \times 10^{5}$ & $1.20 \times 10^{14}$ & \\
\hline & Methanol (g) & $2.89 \times 10^{5}$ & $2.28 \times 10^{8}$ & $6.58 \times 10^{13}$ & \\
\hline & $\mathrm{HCl}(\mathrm{g})$ & $2.15 \times 10^{6}$ & $3.64 \times 10^{9}$ & $7.84 \times 10^{15}$ & \\
\hline & Services (\$) & $1.09 \times 10^{5}$ & $2.22 \times 10^{12}$ & $2.42 \times 10^{17}$ & \\
\hline & Labor (J) & $1.53 \times 10^{10}$ & $7.44 \times 10^{6}$ & $1.14 \times 10^{17}$ & \\
\hline & $\begin{array}{c}\text { Diesel for } \\
\text { transportation }(\mathrm{J})\end{array}$ & $4.39 \times 10^{9}$ & $1.21 \times 10^{5}$ & $5.31 \times 10^{14}$ & \\
\hline \multirow{3}{*}{ Y } & $\begin{array}{l}\text { Output after } \\
\text { biodiesel } \\
\text { production }\end{array}$ & & & & \multirow{3}{*}{ [32] } \\
\hline & Residue (g) & $1.60 \times 10^{9}$ & $5.22 \times 10^{8}$ & $8.37 \times 10^{17}$ & \\
\hline & Algal biodiesel (g) & $1.62 \times 10^{7}$ & $1.69 \times 10^{10}$ & $2.74 \times 10^{17}$ & \\
\hline
\end{tabular}

\subsection{Emergy Indices of Acid-Adapted Microalgal System}

The data on emergy indices such as EYR, ELR, ESI and per cent renewability for the acid-adapted microalgal system as compared to those for active and passive treatment systems are shown in Table 2. The index, EYR, assesses the system's overall contribution to the economy [30]. The larger the net benefit to the society, the higher the EYR. Thus, EYR values $<1.0$ indicate that the emergy yield is less than the emergy invested, indicating that the system is not economically competitive, and if EYR values are $>1.0$, the emergy yield is greater than the emergy invested, which suggests that the system is economically competitive [34]. The present acid-adapted microalgal system of AMD treatment achieves a high 
return on each unit of emergy invested because the EYR value is 1.0. Moreover, the emergy value obtained in the present study is less than the passive and active treatment systems by 1.0 and $8 \%$, respectively. This is mainly due to the use of limited imported inputs in the acid-adapted microalgal treatment system as shown in Table 3. On the other hand, ELR is used to determine how much "pressure" the system exerts on the surroundings. The greater the amount of non-renewable energy utilized, the larger the environmental strain would be. ELR values $<2$ indicate a low environmental impact (or processes that could use large area of a local environment to "dilute the impact"); values between 2 and 10 indicate a moderate environmental impact; and values greater than 10 indicate a relatively concentrated environmental impact [35]. The value of ELR for the present system of AMD treatment is 111, indicating that it has an extreme environmental effect followed by ATS (100) and PTS (13). Despite the use of less acreage of land for PBR construction than the other treatment systems, the ELR value in immobilized acid-adapted microalgal system was much higher. Although more land is used for PTS, the use of solar photovoltaic power results in lower ETR values. Brown and Ulgiati [36] also reported a greater ELR value (263) in the improved sludge treatment process, despite the contribution of higher per cent of renewable input, and suggested that extremely higher ELR might occur from the expenditure of highly concentrated non-renewable energy inputs in a limited local context. However, the ELR value obtained in the present study warrants consideration of adequate renewable inputs to the immobilized microalgal treatment system. If values of ESI are $<1.0$, it indicates that the items or processes are not long-term sustainable. Medium-term sustainability seems to be defined by an ESI value between 1.0 and 5.0, whilst long-term sustainability is considered if the ESI value is higher than 5.0 [36]. In addition, the per cent renewability observed was higher in PTS, followed by ATS and the acid-adapted microalgal treatment system. The overall per cent reduction in renewability in the present system was 9 and $80 \%$ lesser compared to ATS and PTS, respectively.



Figure 1. Emergy analysis in AMD treatment system involving immobilized acid-adapted microalgal strains, Desmodesmus sp. MAS1 and Heterochlorella sp. MAS3. 
Table 2. Emergy indices for the microalgae-based AMD treatment.

\begin{tabular}{ccccc}
\hline \multirow{2}{*}{ Emergy Index } & Unit/Formula & \multicolumn{3}{c}{ Value } \\
\cline { 3 - 5 } & & This Study & PTS * & ATS * \\
\hline Natural renewable & $\left(10^{15} \mathrm{sej}\right)$ & 8.96 & 134 & 25 \\
Natural non-renewable & $\left(10^{15} \mathrm{sej}\right)$ & 1.18 & $\mathrm{NA}$ & $\mathrm{NA}$ \\
Imported inputs & $\left(10^{15} \mathrm{sej}\right)$ & 996 & 1800 & 2500 \\
Yield & $\left(10^{15} \mathrm{sej}\right)$ & 1270 & $\mathrm{NA}$ & $\mathrm{NA}$ \\
Total potential energy & $\mathrm{R}+\mathrm{N}+\mathrm{F}\left(10^{15} \mathrm{sej}\right)$ & 1010 & 1900 & 2500 \\
(Ep) & $\mathrm{Y} / \mathrm{Ep}$ & 1.26 & $\mathrm{NA}$ & $\mathrm{NA}$ \\
Transformity & $(\mathrm{R}+\mathrm{F}) / \mathrm{F}$ & 1.01 & 1.08 & 1.01 \\
EYR & $(\mathrm{F}+\mathrm{N}) / \mathrm{R}$ & 111 & 13 & 100 \\
ELR & $\mathrm{EYR} / \mathrm{ELR}$ & 0.01 & 0.08 & 0.01 \\
ESI & $\mathrm{R} /(\mathrm{F}+\mathrm{R}) \times 100$ & 0.89 & 6.92 & 0.99 \\
\hline Renewability &
\end{tabular}

* Winfrey et al. [27]; PTS = Passive treatment system; ATS = Active treatment system; NA = Not available EYR = Emergy yield ratio; ELR = Environmental loading ratio; ESI = Emergy sustainability index.

Table 3. Direct and indirect greenhouse gas emissions based on Australia's National Greenhouse Energy Reporting (NGER).

\begin{tabular}{|c|c|c|c|c|c|c|}
\hline \multirow{2}{*}{ Process (Transport) } & \multirow{2}{*}{ Input } & \multicolumn{3}{|c|}{ GHG Emissions (Scope 1) } & \multirow{2}{*}{ Total Scope 1 Emission } & \multirow{2}{*}{ Total Energy GJ } \\
\hline & & $\mathrm{CO}_{2}$ & $\mathrm{CH}_{4}$ & $\mathrm{~N}_{2} \mathrm{O}$ & & \\
\hline This study & $0.317 \mathrm{~kL}$ diesel oil & 1 & 0 & 0 & 1 & 12 \\
\hline \multirow{3}{*}{ PTS } & $32.50 \mathrm{~kL}$ diesel oil & 88 & 0 & 1 & 89 & 1255 \\
\hline & \multirow{2}{*}{$3.23 \mathrm{~kL}$ gasoline } & \multirow{2}{*}{7} & \multirow{2}{*}{0} & \multirow{2}{*}{0} & 7 & 110 \\
\hline & & & & & 96 & 1365 \\
\hline \multirow{3}{*}{ ATS } & $47.50 \mathrm{~kL}$ diesel oil & 128 & 0 & 1 & 129 & 1834 \\
\hline & \multirow{2}{*}{6.22 kL gasoline } & \multirow{2}{*}{14} & \multirow{2}{*}{0} & \multirow{2}{*}{0} & 14 & 213 \\
\hline & & & & & 143 & 2046 \\
\hline \multirow{2}{*}{ Process (Purchased Electricity) } & \multirow{2}{*}{ Input } & \multicolumn{3}{|c|}{ Emission Factor } & \multirow{2}{*}{ Total Scope 2 Emission } & \multirow{2}{*}{ Total Energy G] } \\
\hline & & & , Aust & & & \\
\hline \multirow{2}{*}{ This study } & $10.69 \mathrm{kWh}$ & \multirow{2}{*}{\multicolumn{3}{|c|}{0.81}} & 0 & 0 \\
\hline & $641 \mathrm{kWh}$ & & & & 1 & 2 \\
\hline PTS & - & & 0.81 & & - & - \\
\hline ATS & - & & 0.81 & & - & - \\
\hline
\end{tabular}

PTS = Passive treatment system; ATS = Active treatment system .

\subsection{Carbon Foot Printing of Acid-Adapted Microalgal System}

Based on materials and fuel used during the treatment process, acid-adapted microalgal system emitted less $\mathrm{CO}_{2}$, accounting for 4 and $85 \%$ reduction compared to that of ATS and PTS, respectively (Figure 2). The significant source of $\mathrm{CO}_{2}$ in the carbon footprint in the present study is the construction materials (98\%) rather than fuel consumption. However, fuel consumption, in terms of $\mathrm{CO}_{2}$ emission, was significant in other systems accounting for 96 and 74\% in PST and AST, respectively. Lehtoranta et al. [37] reported that the carbon footprint of small ATS, such as batch reactors and fluidized beds, was greater than that of PTS. Similarly, Martinez et al. [5] highlighted that the procurement and transport of concrete and steel bars made a higher contribution during the construction phase, while the acquisition of carbonate materials and their dissolution generated higher impacts during the application phase, suggesting that the alternative sources of greener raw materials should be explored as substitutes for materials in passive treatment of AMD. Moreover, the disposal of the commonly used chemicals such as limestone after precipitation of heavy metals also contributes to the climate change which is reported to be significant compared to the construction phase $[5,7,38]$. Hengen et al. [17] demonstrated that ATS 
using lime slaking had the greatest LCA impacts, while passive treatment approaches had consistently less impacts, except for one PTS with a purchased energy scenario. A $50 \%$ reduction in transportation distances resulted in all the scenarios. We also performed the Scope 1 emissions (which are direct emissions) and Scope 2 (indirect emissions due to electrical power purchased from the grid) GHG emissions based on Australia' s National Greenhouse Energy Reporting (NGER) for the present analysis. In all the treatment processes, the major contributor for the Scope 1 and Scope 2 emission were the electricity and diesel for the acid-adapted microalgal treatment systems, whereas diesel and gasoline were the contributors for both ATS and PTS (Table 3). The total energy consumed was more in ATS and PTS, with majority of the emissions contributed by Scope 1 (diesel and gasoline) while Scope 2 (purchased electricity) alone contributed to the acid-adapted microalgal treatment system. Such a low emissions, based on NGER Scope 1, from the acid-adapted technology are associated with the use of less diesel in transportation of construction materials. However, Scope 2 emissions were prevalent in acid-adapted microalgal systems due to the purchase of electricity for pumping of AMD effluent to the reactor, whereas the conventional systems employ a photovoltaic panel for sourcing electricity for the treatment process, as indicated in Table 3. Additionally, both PTS and ATS contributed $\mathrm{N}_{2} \mathrm{O}$ emissions, with a 100-fold increase by diesel compared to the acid-adapted algal AMD treatment process (Table 3). On the contrary, emergy analysis indicated that construction material influenced $\mathrm{CO}_{2}$ emission more significantly than diesel consumption, which is consistent with the results reported by Winfrey et al. [27]. This is because emergy analysis considers the resource use including both renewable and non-renewable inputs rather than construction and diesel consumption that result in less disparity between the systems than carbon footprint analysis [38].

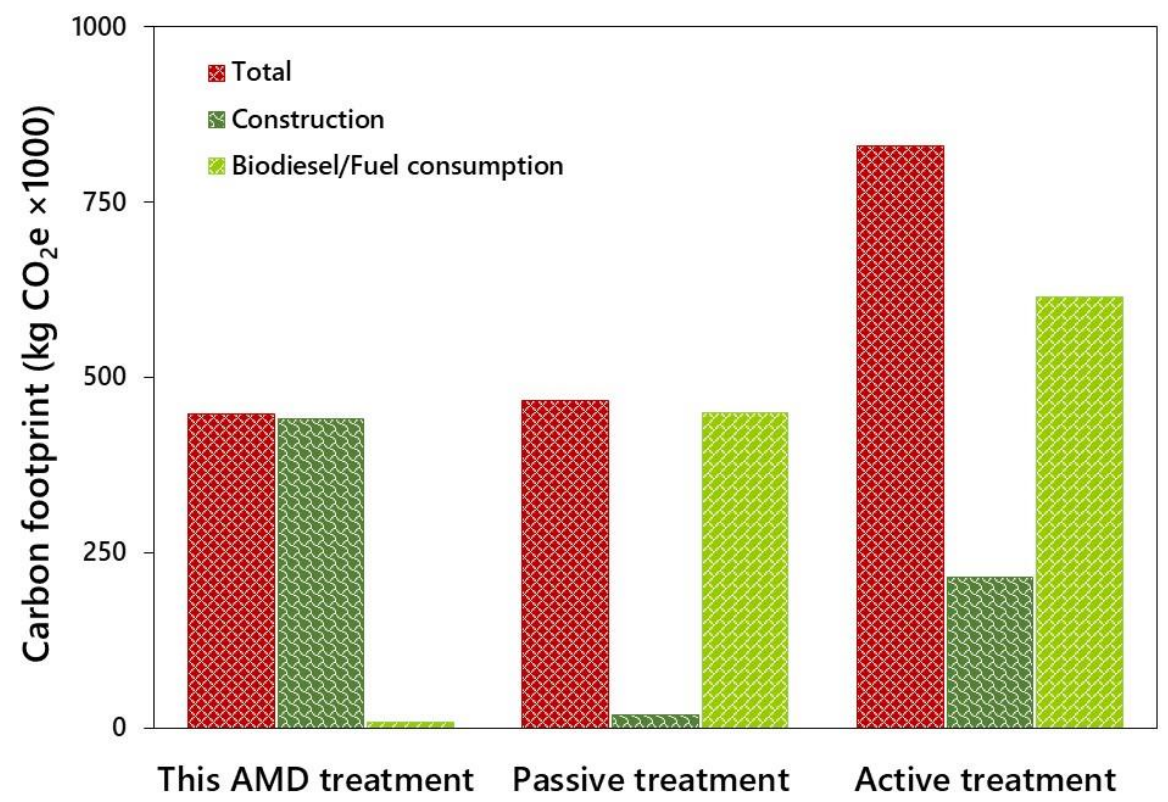

Figure 2. A comparison of carbon footprint - this AMD treatment (immobilized microalgal system), passive treatment [27], and active treatment [27] of AMD.

\section{Materials and Methods}

\subsection{Emergy Accounting}

Following the principles of Odum [30], the sustainability of the acid-adapted microalgal technology proposed for acid mine drainage treatment was evaluated via emergy analysis. Emergy is defined as "the quantity of energy (particularly solar emergy) used to develop a resource, both directly and indirectly" [30]. Emergy measures the worth of resources, products, and services in a single unit of energy called solar emergy, which is measured in solar emjoules (sej). All system inputs such as energy, materials, and services are transformed 
to energy units using a conversion factor termed "transformity" throughout the analysis. The efficiency index is defined as the amount of solar energy necessary to deliver a joule of a product or service (sej/J). For example, the relationship between emergy of a biomass $\left(E m_{i}\right)$ and its energy content $\left(E_{i}\right)$ is given by transformity $\left(\operatorname{Tr}_{i}\right)$ as shown in the equation:

$$
\operatorname{Tr}_{i}=\frac{E m_{i}}{E_{i}}
$$

Since solar emergy is the starting point for all other emergy calculations, the transformity of solar energy is set to unity [39]. If the transformity is greater, more environmental assistance is needed to make a product unit accessible [40]. Transformity calculations, in general, have inherent uncertainty in them due to their sensitivity [30]. To address this, researchers employ different approaches to analyzing transformity uncertainty. Thus, several studies have used emergy analysis to compare resource consumption intensity, trade balance, and sustainable production in a variety of systems. Even the application of emergy to geographical locations has resulted in a unique understanding of the regions' ecology and economy.

Overall, emergy analysis is conducted in a series of easy procedures that include designing a system input and output flow diagram, noting the emergy flows of each item, and computing the emergy indicators. Traditional emergy analysis provides metrics that are ideal for analyzing the system's ecological and economic prospects to determine longterm growth of the process. Figure 3 depicts the emergy flow diagram, where " $R$ " denotes a renewable resource found in nature, " $\mathrm{N}$ " denotes non-renewable energy input, " $\mathrm{F}$ " denotes bought non-renewable energy input from the socioeconomic system, and " $\mathrm{Y}$ " is emergy production of the process.



Figure 3. Schematic representation of emergy flow accounting for local renewable energy inputs (R), local non-renewable inputs $(\mathrm{N})$, and purchased inputs from outside the system $(\mathrm{F})$.

\subsection{Net Emergy and Emergy Yield Ratio}

The concept of net emergy has been defined as "the emergy yield minus feedback input of a process" [30] and emergy yield ratio (EYR) is "the ratio of the amount of emergy produced $(\mathrm{Y})$ to the emergy purchased from outside the system of society $(\mathrm{F})$ ". The greater the fraction of locally available energy sources $(R+N)$ which are used by means of the investment $\mathrm{F}$, the higher the value of this indicator. EYR helps in predicting the emergy efficiency and economic competitiveness of a local resource based on purchased inputs. 


\subsection{Environmental Loading Ratio}

Environmental loading ratio (ELR) is the sum of non-renewable resource $(\mathrm{N})$ and purchased emergy (F) divided by renewable resource emergy (R). This expresses the environmental services used by the system. When a high value of local renewable resources is used, then ELR decreases, thus indicating a small environmental stress. On the contrary, when a high value of local non-renewable resources is used, it results in an increase in ELR values, thus suggesting a greater environmental stress.

\subsection{Emergy Sustainability Index}

The emergy sustainability index (ESI) was calculated by dividing the EYR by the ELR as it is especially useful for comparing different processes. A sustainable process should expand the ESI. Renewability is a relative measure of per cent renewable of a process or proportion of the total emergy required for a process that is derived from renewable sources.

\subsection{System Boundary of Acid-Adapted Microalgae in AMD Treatment}

In a previous study, the LCA method was used in the AMD treatment process employing immobilized microalgal system and measured the extent of global warming, acidification, eutrophication, cumulative energy demand, and water consumption consequences [25]. These findings showed that acid-adapted microalgal strains in immobilized technology outperformed limestone or hybrid microalgal treatment systems in terms of environmental sustainability. Following emergy analysis, here we evaluated the environmental and economic perspective of the treatment method by assuming treatment facility installed on a hectare $\left(10,000 \mathrm{~m}^{2}\right)$ closer to the mine. Treatment efficiency, recovery, and biodiesel were used in the previous study as inputs for the analysis [25]. Other factors such as solar, wind, and geothermal energies were considered for the Newcastle, Australia area. The AMD treatment approach was examined here from the point of entrance into the treatment system through return of the treated water and the algal biomass to produce value-added products. Emergy inputs include renewable resource emergy, non-renewable resource emergy, and social and services feedback resource emergy. Wastewater treatment, production of microalgal biomass and biodiesel, and the application of algal residue to agricultural land were also included in the present study. A comprehensive assumption and calculation of the emergy data are presented in Table S1. Furthermore, the results of the present study were compared with those of (i) an active treatment system that included an aeration tank, a neutralization basin for lime dosing, and a clarifier, (ii) a passive treatment system that included an oxidation pond, two wetlands, vertical flow bioreactors, re-aeration ponds, and horizontal flow limestone beds, and (iii) a common final polishing cell with emergy value as adopted in the study [27].

\subsection{Carbon Footprint Analysis}

To calculate the carbon footprint, carbon dioxide equivalents $\left(\mathrm{CO}_{2} \mathrm{e}\right)$ were used [27]. $\mathrm{CO}_{2}$, methane $\left(\mathrm{CH}_{4}\right)$, and nitrous oxide $\left(\mathrm{N}_{2} \mathrm{O}\right)$ were transformed to $\mathrm{CO}_{2} \mathrm{e}$ based on their respective global warming potential, usually calculated on a mass basis [41]. $\mathrm{CH}_{4}$ and $\mathrm{N}_{2} \mathrm{O}$ have global warming potentials of $25 \mathrm{~g} \mathrm{CH}_{4} / \mathrm{g} \mathrm{CO}_{2} \mathrm{e}$ and $298 \mathrm{~g} \mathrm{~N}_{2} \mathrm{O} / \mathrm{g} \mathrm{CO}_{2} \mathrm{e}$, respectively [41]. All the materials and fuels used during construction were multiplied by their corresponding emission factors to calculate the carbon footprint of a system. The emergy analysis of the passive treatment system (PTS) and active treatment system (ATS) used emission factors established in the literature to multiply the construction material inputs and fuel use [42-44]. In addition, direct Scope 1 and indirect Scope 2 emissions were calculated based on Australian National Energy Reporting System [45]. For this, the electricity data and diesel consumption were used in appropriate index to generate $\mathrm{CO}_{2}$ equivalent values. 


\section{Conclusions}

The present study evaluated the sustainability of immobilized acid-adapted microalgal system for bioremediation of AMD by comparing with ATS and PTS following emergy and carbon footprint analysis. Emergy analysis showed that renewable energy input was extremely low in the case of the microalgal treatment system, although the total emergy value was lower than in other treatment systems. This was consistent with emergy indices, particularly with higher ELR value and lower per cent renewability than for PTS and ATS. The emergy yield ratio was close to 1.0, indicating a high return on each unit of emergy invested from the treatment process. In addition, CFA revealed that $\mathrm{CO}_{2}$ emission in microalgal treatment system was reduced by 80 and $5 \%$ compared to ATS and PTS. The primary source of $\mathrm{CO}_{2}$ is the construction materials for acid-adapted microalgal treatment process and diesel consumption for the other treatment processes. NGER-based analysis also indicated that energy consumption was greater in ATS and PTS than in microalgal technology as energy is derived from biodiesel produced in the latter system. However, Scope 1 emission in acid-adapted microalgal technology was significantly lower than in ATS and PTS, whereas Scope 2 emission was higher in the former system. Overall, the use of immobilized acid-adapted microalgae for AMD remediation is environmentally friendly and the observed sustainability can be improved by incorporating more renewable energy inputs.

Supplementary Materials: The following are available online. Table S1: Assumptions and calculation of emergy data of immobilized acid- adapted treatment system for AMD bioremediation; Table S2: Summary of direct and indirect emissions of the treatment process.

Author Contributions: Conceptualization, K.P., S.A. and M.M.; methodology, K.P. and S.A.; validation, K.P. and S.A.; formal analysis, K.P. and S.A.; investigation, K.P. and S.A.; data curation, K.P. and S.A.; writing —original draft preparation, S.A.; writing—review and editing, S.A., K.V. and M.M.; visualization, K.V.; supervision, M.M.; project administration, M.M.; funding acquisition, M.M. All authors have read and agreed to the published version of the manuscript.

Funding: This research received no external funding.

Institutional Review Board Statement: Not applicable.

Informed Consent Statement: Not applicable.

Data Availability Statement: Not applicable.

Acknowledgments: K.P. and S.A. acknowledge the University of Newcastle for providing ViceChancellor's HDR Training Scholarship and RTP Scholarship for supporting PhD program. The authors sincerely appreciate Anithadevi Kenday Sivaram for helping in proof checking.

Conflicts of Interest: The authors declare no conflict of interest.

Sample Availability: Not applicable.

\section{References}

1. Abinandan, S.; Subashchandrabose, S.R.; Venkateswarlu, K.; Megharaj, M. Microalgae-bacteria biofilms: A sustainable synergistic approach in remediation of acid mine drainage. Appl. Microbiol. Biotechnol. 2018, 102, 1131-1144. [CrossRef] [PubMed]

2. Johnson, D.B.; Hallberg, K.B. Acid mine drainage remediation options: A review. Sci. Total Environ. 2005, 338, 3-14. [CrossRef] [PubMed]

3. Simate, G.S.; Ndlovu, S. Acid mine drainage: Challenges and opportunities. J. Environ. Chem. Eng. 2014, 2, 1785-1803. [CrossRef]

4. Abinandan, S.; Subashchandrabose, S.R.; Venkateswarlu, K.; Megharaj, M. Sustainable iron recovery and biodiesel yield by acid-adapted microalgae, Desmodesmus sp. MAS1 and Heterochlorella sp. MAS3, grown in synthetic acid mine drainage. Acs Omega 2020, 5, 6888-6894. [CrossRef]

5. Martínez, N.M.; Basallote, M.D.; Meyer, A.; Cánovas, C.R.; Macías, F.; Schneider, P. Life cycle assessment of a passive remediation system for acid mine drainage: Towards more sustainable mining activity. J. Clean. Prod. 2019, 211, 1100-1111. [CrossRef]

6. Nleya, Y.; Simate, G.S.; Ndlovu, S. Sustainability assessment of the recovery and utilisation of acid from acid mine drainage. J. Clean. Prod. 2016, 113, 17-27. [CrossRef] 
7. Rosso, D.; Bolzonella, D. Carbon footprint of aerobic biological treatment of winery wastewater. Water Sci. Technol. 2009, 60, 1185-1189. [CrossRef]

8. Abinandan, S.; Shanthakumar, S. Challenges and opportunities in application of microalgae (Chlorophyta) for wastewater treatment: A review. Renew. Sustain. Energy Rev. 2015, 52, 123-132. [CrossRef]

9. Al Ketife, A.M.; Judd, S.; Znad, H. Optimization of cultivation conditions for combined nutrient removal and $\mathrm{CO}_{2}$ fixation in a batch photobioreactor. J. Chem. Technol. Biotechnol. 2017, 92, 1085-1093. [CrossRef]

10. Abinandan, S.; Subashchandrabose, S.R.; Venkateswarlu, K.; Megharaj, M. Nutrient removal and biomass production: Advances in microalgal biotechnology for wastewater treatment. Crit. Rev. Biotechnol. 2018, 38, 1244-1260. [CrossRef]

11. Naderi, G.; Znad, H.; Tade, M.O. Investigating and modelling of light intensity distribution inside algal photobioreactor. Chem. Eng. Process. 2017, 122, 530-537. [CrossRef]

12. Judd, S.J.; Al Momani, F.; Znad, H.; Al Ketife, A. The cost benefit of algal technology for combined $\mathrm{CO}_{2}$ mitigation and nutrient abatement. Renew. Sustain. Energy Rev. 2017, 71, 379-387. [CrossRef]

13. Hena, S.; Znad, H.; Heong, K.; Judd, S. Dairy farm wastewater treatment and lipid accumulation by Arthrospira Platensis. Water Res. 2018, 128, 267-277. [CrossRef]

14. Almomani, F.; Al Ketife, A.; Judd, S.; Shurair, M.; Bhosale, R.R.; Znad, H.; Tawalbeh, M. Impact of $\mathrm{CO}_{2}$ concentration and ambient conditions on microalgal growth and nutrient removal from wastewater by a photobioreactor. Sci. Total Environ. 2019, 662, 662-671. [CrossRef]

15. ISO 14040: Environmental Management-Life Cycle Assessment-Principles and Framework; International Organization for Standardization: Geneva, Switzerland, 1997.

16. US EPA. Inventory of US Greenhouse Gas Emissions and Sinks: 1990-2009; US Environmental Protection Agency: Washington, DC, USA, 2011

17. Hengen, T.J.; Squillace, M.K.; O'Sullivan, A.D.; Stone, J.J. Life cycle assessment analysis of active and passive acid mine drainage treatment technologies. Resour. Conserv. Recycl. 2014, 86, 160-167. [CrossRef]

18. Maiolo, S.; Cristiano, S.; Gonella, F.; Pastres, R. Ecological sustainability of aquafeed: An emergy assessment of novel or underexploited ingredients. J. Clean. Prod. 2021, 294, 126266. [CrossRef]

19. Odum, H.T. Systems Ecology: An Introduction; Wiley and Sons: Hoboken, NJ, USA, 1983; ISBN 0471652776.

20. Zhang, M.; Wang, Z.; Xu, C.; Jiang, H. Embodied energy and emergy analyses of a concentrating solar power (CSP) system Energy Policy 2012, 42, 232-238. [CrossRef]

21. Amaral, L.P.; Martins, N.; Gouveia, J.B. A review of emergy theory, its application and latest developments. Renew. Sustain. Energy Rev. 2016, 54, 882-888. [CrossRef]

22. Liu, Z.; Adams, M.; Cote, R.P.; Geng, Y.; Ren, J.; Chen, Q.; Liu, W.; Zhu, X. Co-benefits accounting for the implementation of eco-industrial development strategies in the scale of industrial park based on emergy analysis. Renew. Sustain. Energy Rev. 2018, 81, 1522-1529. [CrossRef]

23. Björklund, J.; Geber, U.; Rydberg, T. Emergy analysis of municipal wastewater treatment and generation of electricity by digestion of sewage sludge. Resour. Conserv. Recycl. 2001, 31, 293-316. [CrossRef]

24. Zhang, X.; Deng, S.; Wu, J.; Jiang, W. A sustainability analysis of a municipal sewage treatment ecosystem based on emergy. Ecol. Eng. 2010, 36, 685-696. [CrossRef]

25. Abinandan, S.; Praveen, K.; Subashchandrabose, S.R.; Venkateswarlu, K.; Megharaj, M. Life cycle assessment for the environmental sustainability of the immobilized acid-adapted microalgal technology in iron removal from acid mine drainage. Acs Sustain. Chem. 2020, 8, 15670-15677. [CrossRef]

26. Wiedmann, T. Carbon footprint and input-output analysis-an introduction. Econ. Syst. Res. 2009, 21, 175-186. [CrossRef]

27. Winfrey, B.; Nairn, R.; Tilley, D.; Strosnider, W. Emergy and carbon footprint analysis of the construction of passive and active treatment systems for net alkaline mine drainage. Mine Water Environ. 2015, 34, 31-41. [CrossRef]

28. NGER. National Greenhouse and Energy Reporting Scheme Measurement-Technical Guidelines for the Estimation of Emissions by Facilities in Australia (August 2016); Department of the Environment and Energy, Australian Government: Canberra, Australia, 2016. Available online: https://www.environment.gov.au (accessed on 12 December 2021).

29. da Cruz, R.V.A.; do Nascimento, C.A.O. Emergy analysis of oil production from microalgae. Biomass Bioenergy 2012, 47, 418-425. [CrossRef]

30. Odum, H.T. Environmental Accounting: Emergy and Environmental Decision Making; John Wiley \& Sons: New York, NY, USA, 1996; ISBN 9780471114420

31. Alizadeh, S.; Zafari-Koloukhi, H.; Rostami, F.; Rouhbakhsh, M.; Avami, A. The eco-efficiency assessment of wastewater treatment plants in the city of Mashhad using emergy and life cycle analyses. J. Clean. Prod. 2020, 249, 119327. [CrossRef]

32. Jarméus, C. Emergy Analysis of Biodiesel and Biogas Production from Baltic Sea Macro Algae. Master's Thesis, KTH Royal Institute of Technology, Stockholm, Sweden, 2013.

33. Shao, L.; Chen, G. Renewability assessment of a production system: Based on embodied energy as emergy. Renew. Sustain. Energy Rev. 2016, 57, 380-392. [CrossRef]

34. Yang, H.; Li, S. Emergy analysis of cassava vinasse treatment. Process Saf. Environ. Prot. 2013, 91, 503-507. [CrossRef]

35. Brown, M.; Ulgiati, S. Emergy Analysis and Environmental Accounting. In Encyclopedia of Energy; Elsevier: Oxford, UK, $2004 ;$ p. 354. 
36. Brown, M.T.; Ulgiati, S. Emergy evaluations and environmental loading of electricity production systems. J. Clean. Prod. 2002, 10, 321-334. [CrossRef]

37. Lehtoranta, S.; Vilpas, R.; Mattila, T. Comparison of carbon footprints and eutrophication impacts of rural on-site wastewater treatment plants in Finland. J. Clean. Prod. 2014, 65, 439-446. [CrossRef]

38. Gusek, J.; Josselyn, L.; Agster, W.; Lofholm, S.; Millsap, D. In Process selection and design of a passive treatment system for the Empire Mine State Historic Park. In Proceedings of the 28th National Conference ASMR, Bismarck, ND, USA, 11-16 June 2011; pp. 232-253.

39. Hau, J.L.; Bakshi, B.R. Promise and problems of emergy analysis. Ecol. Model. 2004, 178, 215-225. [CrossRef]

40. Carraretto, C.; Macor, A.; Mirandola, A.; Stoppato, A.; Tonon, S. Biodiesel as alternative fuel: Experimental analysis and energetic evaluations. Energy 2004, 29, 2195-2211. [CrossRef]

41. Forster, P.; Ramaswamy, V.; Artaxo, P.; Berntsen, T.; Betts, R.; Fahey, D.W.; Haywood, J.; Lean, J.; Lowe, D.C.; Myhre, G.; et al. Changes in Atmospheric Constituents and in Radiative Forcing. In Climate Change 2007: The Physical Science Basis. Contribution of Working Group I to the Fourth Assessment Report of the Intergovernmental Panel on Climate Change; Solomon, S., Qin, D., Manning, M., Chen, Z., Marquis, M., Averyt, K.B., Tignor, M., H.L. Miller, H.L., Eds.; Cambridge University Press: Cambridge, UK; New York, NY, USA, 2007.

42. Marceau, M.L.; Nisbet, M.A.; Van Geem, M.G. Life Cycle Inventory of Portland Cement Concrete; Portland Cement Association: Skokie, IL, USA, 2007.

43. IPCC. Emissions Factor Database. In Emissions Factor Database; IPCC: Kyoto, Japan, 2006; Available online: http://www.ipccnggip.iges.or.jp/EFDB/main.php (accessed on 12 December 2021).

44. US EPA (US Environmental Protection Agency). Emissions Factors for Greenhouse Gas Inventories; US EPA: Washington, DC, USA, 2011.

45. National Greenhouse and Energy Reporting. Emissions and Energy Threshold Calculator User Guide. 2021. Available online: http:/ / www.cleanenergyregulator.gov.au/DocumentAssets/Pages/NGER-Emissions-and-Energy-Threshold-Calculator2020-21.aspx (accessed on 20 December 2021). 